dissolution of the network, freeing the vesicle for exocytosis at the presynaptic membrane.

For the process of chromaffin granule secretion, it was suggested ${ }^{2}$ that the secreting granules are crosslinked within a fodrin/actin cytoskeleton in the resting state and are released following network disassembly that, as in the synapse, is secondary to calcium influx, activation of calcium/calmodulin-dependent protein kinase, and the phosphorylation of an as yet unidentified granule membrane or cytosolic component".

Might this component be a synapsinlike molecule? In a study directed at determining which chromaffin granule membrane proteins become phosphorylated when stimulated in the presence of $\left[\gamma^{32} \mathrm{P}\right] \mathrm{ATP}^{10}$, polypeptides of $M_{\mathrm{r}} 60,000$ (tyrosine hydroxylase) were described. It is of interest to note, however, that careful examination of their autoradiograph reveals additional labelling of polypeptides of about $M_{r} 73,000$, remarkably similar to those found for synapsin Ia and $\mathrm{Ib}$ on discontinuous SDS-PAGE. Furthermore, in one of the early synapsin

\section{Impact cratering and flood basalt volcanism}

SIR-Two contrasting causal mechanisms for the mass extinctions at the Cretaceous/ Tertiary $(\mathrm{K} / \mathrm{T})$ boundary at $66 \mathrm{Myr}$ BP continue to be the subjects of intense debate: (1) a comet or asteroid impact (or several impacts during a comet shower)', and (2) increased volcanic activity, as summarized recently by Officer et al. ${ }^{2}$. Evidence for a large-body impact is strong - a worldwide ejecta layer containing anomalous iridium, with microspherules and shocked minerals, coincides closely in time with the mass extinctions on land and in the sea'. There are also several candidate $\mathrm{K} / \mathrm{T}$ craters on the continents, although none so large (100 to $200 \mathrm{~km}$ in diameter) as suggested by the composition of the impact layer. On the other hand, recent study shows that the great Deccan flood basalts in India were erupted in a period of only 1-3 Myr, also coinciding with the K/T boundary ${ }^{3}$, and with possible widespread environmental effects ${ }^{4}$.

The seeming coincidence raises the question: could flood basalt eruptions and large-body impacts be causally related? Impacts might lead to basaltic volcanism directly by penetrating and deeply fracturing the Earth's crust, allowing magma to reach the surface, or by causing pressurerelease melting in the upper mantle by the excavation and removal of crustal rocks, and thus triggering a rising plume of magmas. Very large impacts might also indirectly trigger volcanism through seismic disturbances at pre-existing volcanically active zones, but this is very uncertain. The major question is: how deeply do studies $^{11}$, the molecule (then known as Protein I) was shown to be abundant in the adrenal medulla. Determining whether synapsin is confined to nerve terminals in this tissue or whether it is also present in chromaffin cells may allow what has been learned about neurotransmitter release in the brain to be applied to the molecular mechanism of chromaffin cell exocytosis.

Department of Anatomy,

University of Pennsylvania School of Medicine,

Philadelphia, Pennsylvania 19104, USA

Perrin, D., Langely, D.K. \& Aunis, D. Nature 326, 498501 (1987)

2. Burgoyne, R.D. \& Cheek, T.R. Nature 326, 448 (1987)

3. Bahler, M. \& Greengard, P. Nature 326, 704-707 (1987)

4. Baines, A.J. Nature 326, 646 (1987).

Baines, A.J. \& Bennett, V. Nature 315, 410-413 (1985).

Goodman, S.R. \& Zagon, I.S. Am. J. Physiol. 250, 347 $360(1986)$

Siegel, D.L. \& Branton, D. J. Cell Biol. 100, 775-785 (1985)

8. Krebs, K.E., Zagon, I.S. \& Goodman, S.R. J. Cell Biol. 103, 2829a (1986)

9. Trifaro, J.-M., Bader, M.-F. \& Doucet, J.-P. Can. J. Biochem. Cell Biol. 63, 661-679 (1985).

0. Burgoyne, R.D. \& Geisow, M.J. FEBS Lett. 131, 127-131 (1981)

1. DeCamilli, P., Ueda, T., Bloom, F.E., Battenberg, E. \& Greengard, P. Proc. nutn. Acad. Sci. U.S. A. 76, 5977-5981 (1979)

large-body impacts excavate the Earth's surface? Or more generally: what is the depth/diameter ratio for large impact craters? Two studies reported at the recent 18th Lunar and Planetary Science Conference in Houston have now provided quantitative evidence for an answer ${ }^{6.7}$

Previous work showed that small impacts form simple, bowl-shaped craters $^{8}$ with a true depth $(d)$ to diameter $(D)$ ratio, $d / D=0.2$ to 0.3 (taking into account partial fill by impact breccia ${ }^{x}$. At diameters above about $1-2 \mathrm{~km}$ in sedimentary targets and $3-4 \mathrm{~km}$ in crystalline targets, however, terrestrial impact craters have a complex form, with a central core of uplifted, shocked rocks surrounded by one or more concentric depressions (terraces formed by faulting and slumping of the outer portion of the crater). These features apparently represent collapse of the initial crater and isostatic rebound of the underlying crust and mantle as they adjust to the sudden removal of the surface rocks". Most studies agree that the final crater form for large impact craters should therefore be quite shallow $(d / \mathrm{D}=0.1$ to 0.006 in some cases) and this agrees with observations for large craters on the Moon and other terrestrial planets ${ }^{10}$.

But what about the depth of the initial transient crater produced during large impacts? Although it has been claimed that large craters might be initially quite shallow (see, for example, ref. 10), with only minimal penetration on impact, two recent studies suggest that the depth of excavation of large terrestrial craters is great enough to have considerable geological effects on the lower crust and upper mantle. In the most recent detailed modelling of impact penetration and later crater readjustment, O'Keefe and Ahrens ${ }^{6}$ show that for high accelerations and large scales, a deep transient bowlshaped crater is always produced. They conclude that the initial crater morphology is given by $d_{\mathrm{e}} r=0.002 r^{0.2}$ (in c.g.s. units, where $d_{\mathrm{e}}$ is the depth of excavation, $r$ is the crater radius, for the Earth's gravity and an impact velocity of $12 \mathrm{kms}^{-1}$ ). This agrees in general with earlier work by Orphal $^{11}$ and Melosh ${ }^{9}$, and indicates that large impact craters should have had deep initial penetration cavities.

If the above relationship holds true, then the transient depth of excavation of a $100-200 \mathrm{~km}$ diameter crater on the earth (as proposed for a $10-\mathrm{km}$ diameter impactor at the $\mathrm{K} / \mathrm{T}$ boundary) would be in the range of about $20-40 \mathrm{~km}$; deep enough to penetrate easily through the 5$\mathrm{km}$-thick ocean crust, and even deep enough to excavate much or all of the thicker continental crust. This supports the evidence presented at the same conference by Hildebrand and Boynton? which shows that the $\mathrm{K} / \mathrm{T}$ ejecta layer has a substantial mantle component. Rareearth element abundance patterns in the boundary layer can be explained by a mixture of ocean crust, continental sediments and oceanic mantle; the fraction of mantle material indicates a minimum depth of cratering of about $40 \mathrm{~km}$. These results suggest that the crater produced by the proposed $\mathrm{K} / \mathrm{T}$ impactor could have been deep enough to generate directly volcanism in an oceanic impact, or create deep fractures in the lower continental crust. Perhaps the target areas(s) for the largest $\mathrm{K} / \mathrm{T}$ impactor(s) lies beneath the Deccan Traps, the Iceland hotspot (the source of the Brito-Arctic basalt eruptions), or some other hotspot or oceanic plateau ${ }^{12}$. The extinctions at the $\mathrm{K} / \mathrm{T}$ boundary might therefore be related both to impact and volcanic phenomena.

Michael R. Rampino

Department of Applied Science,

New York University,

New York

New York 10003, USA

and

NASA, Goddard Institute for Space

Studies, New York,

New York 10025, USA

Alvarez, W. Eos 67, 649-658 (1987).

Officer, C.B., Hallam, A. Drake, C.L. \& Devine, J.D Nature 326, 143-149 (1987)

3. Courtillot, V. et al. Earth planet. Sci, Lett. 80, 361-374 (1986)

4. Stothers, R.B., Wolff. J.A., Self, S. \& Rampino, M.R. Geophys. Res. Lett. 13, 725-728 (1986)

Green, D.H. Earth planet. Sci. Lett. 15. 263-270 (1972).

6. O'Keefe, J.D. \& Ahrens, T.J. Abstr. Eighteenth Lunar Planetary Sce. Conf. 744-745 (1987).

7. Hildebrand, A.R. \& Boynton, W.V. Abstr. Eighteenth Lunar Planetary Sci. Conf. 427-428 (1987).

8. Grieve, R.A.F. Spec. Pap. geol. Soc. Am. 190, 25-37 (1982)

9. Melosh. H.J. J. geophys. Res. 87, 371-380 (1982)

10. Pike, R.J. Icarus 43, 1-19(1980)

11. Orphal, D.L. Abstr. Tenth Lunar Planetary Sci Conf. 949951 (1979).

12. Rodgers. G.C. Nature 299, 341-342 (1982). 